\title{
PEMBERDAYAAN KELOMPOK NELAYAN DALAM PEMBUATAN IKAN ASAP DAN PEMANFAATAN LIMBAH PERIKANAN MENJADI PAKAN PUYUH DI DESA KUALA TAMBANGAN KABUPATEN TANAH LAUT
}

\author{
Anton Kuswoyo ${ }^{1 *}$, Mufrida Zein ${ }^{2}$, dan Rusuminto Syahyuniar ${ }^{3}$ \\ 1,2,3 Politeknik Negeri Tanah Laut, Jl. A. Yani Km. 06 Desa Panggung, Kecamatan Pelaihari \\ Kabupaten Tanah Laut - Kalimantan Selatan \\ *Penulis korespondensi: kuswoyoanton@politala.ac.id
}

\begin{abstract}
Abstrak: Kelompok nelayan "Mandiri Putra" Desa Kuala Tambangan Kecamatan Takisung Kabupaten Tanah Laut, merupakan sekumpulan nelayan yang setiap hari bekerja mencari ikan di laut. Terdiri dari 10 anggota. Mereka menangkap ikan menggunakan pukat, jaring, jala, dan pancing. Biasanya dalam satu perahu memuat 2-3 pekerja (awak perahu) yang membantu menangkap ikan. Para nelayan menghadapi tiga permasalahan yaitu: harga ikan hasil tangkapan naik turun dan bahkan cenderung murah sehingga penghasilan nelayan pas-pasan; sebagian hasil tangkapan (25\%-30\%) hanya menjadi limbah yang tidak laku dijual serta belum dimanfaatkan sehingga mengurangi pendapatan nelayan; dan selama ini mitra belum memiliki kemampuan mengolah hasil perikanan, belum memiliki keterampilan pemasaran produk (ikan hasil tangkapan), sehingga masih sangat tergantung pada tengkulak ikan. Maka solusi yang diterapkan pada kelompok nelayan tersebut adalah melatih pembuatan ikan asap dan mengolah limbah perikanan menjadi pakan puyuh sehingga meningkatkan harga jual ikan. Selain itu juga meningkatkan nilai guna limbah perikanan menjadi pakan puyuh. Nelayan juga dilatih memasarkan produk dan manajemen usaha. Hasilnya, nelayan telah mampu membuat ikan asap dan pakan puyuh dari limbah perikanan. Nelayan juga mulai mampu memasarkan produk sehingga menambah penghasilan.
\end{abstract}

Kata kunci: Ikan asap, limbah perikanan, nelayan, pakan puyuh.

\begin{abstract}
The "Mandiri Putra" fishing group, Kuala Tambangan Village, Takisung District, Tanah Laut Regency, is a group of fishermen who work every day to fish in the sea. Consists of 10 members. They catch fish using trawls, nets, nets and fishing rods. Usually a boat contains 2-3 workers (boat crew) who help catch fish. The fishermen face three problems, namely: the price of the fish they catch fluctuates and even tends to be cheap so that the income of the fishermen is mediocre; part of the catch $(25 \%-30 \%)$ is only waste that is unsold for sale and has not been utilized, thereby reducing fishermen's income; and so far partners do not have the ability to process fishery products, do not have product marketing skills (catch fish), so they are still very dependent on fish middlemen. So the solution applied to the fishermen group is to train the manufacture of smoked fish and process fishery waste into quail feed, thereby increasing the selling price of fish. In addition, it also increases the use value of fishery waste into quail feed. Fishermen was also trained in product marketing and business management. As a result, fishermen have been able to make smoked fish and quail feed from fishery waste. Fishermen have also begun to be able to market their products so as to increase their income.
\end{abstract}

Keywords: Smoked fish, fishery waste, fishermen, quail feed.

\section{PENDAHULUAN}

Kelompok nelayan "Mandiri Putra" Desa Kuala Tambangan Kecamatan Takisung Kabupaten Tanah Laut, merupakan sekumpulan nelayan yang setiap hari bekerja mencari ikan di laut. Terdiri dari 10 anggota. Mereka menangkap ikan menggunakan pukat, jaring, jala, dan pancing. Berlayar ke lautan menggunakan perahu bermotor. Biasanya dalam satu perahu memuat 2-3 pekerja (awak perahu) yang membantu mereka menangkap ikan.

Desa Kuala Tambangan merupakan salah satu desa prioritas/desa pilot yang dicanangkan 
pemerintah pusat sebagai desa mitra kegiatan pengabdian (Gambar 1). letaknya di pesisir pantai, sehingga mayoritas penduduknya berprofesi sebagai nelayan, (www.port.tanahlautkab.go.id).

Rata-rata per hari mampu menangkap ikan sebanyak 80 kg. Harga jual ikan Rp 7.000/kg. Dari $80 \mathrm{~kg}$ hasil tangkapan, sebanyak $20 \mathrm{~kg}$ berupa limbah ikan berupa ikan-ikan kecil dan ikan yang rusak yang tidak laku dijual. Sehingga hasil tangkapan sebanyak $60 \mathrm{~kg}$ dikali harga $\mathrm{Rp} 7.000$, total Rp 420.000,-. Dikurangi biaya solar, makan, dan upah pekerja, sisanya hanya sekitar Rp 130.000,per hari. Para nelayan bekerja selama 24 hari dalam sebulan. Sehingga penghasilan bersih \pm Rp 3.120.000/bulan. Hasil ini masih belum dikurangi untuk biaya perbaikan perahu, mesin, maupun peralatan tangkap ikan. Jika musim gelombang besar, para nelayan tidak bisa pergi melaut, sehingga nyaris dalam satu bulan tidak mendapatkan hasil sama sekali.

Setiap bulan selalu ada yang diperbaiki, misalnya mesin perahu, peralatan tangkap ikan, dll. Sehingga memerlukan biaya tambahan diluar pengeluaran rutin. Harga ikan juga sering turun naik, tidak stabil. Pernah harga ikan sampai Rp $5.000 / \mathrm{kg}$. Sedangkan pengeluaran tetap. Hal ini tentu sangat merugikan para nelayan.

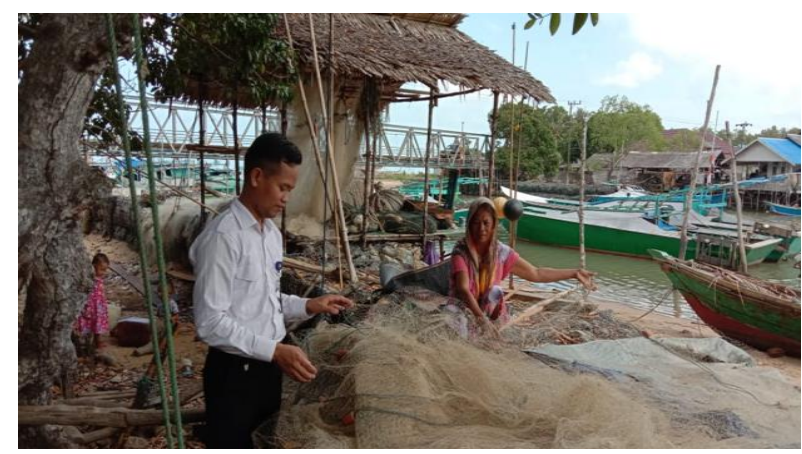

Gambar 1. Ketua tim (Anton Kuswoyo, S.Si., M.T.) berdiskusi dengan nelayan yang sedang melakukan perbaikan alat penangkap ikan. (Sumber: Kuswoyo, 2019)

Saat angin kencang dan gelombang besar, para nelayan tidak bisa melaut (menangkap ikan di laut). Kejadian seperti ini kadang hampir satu bulan penuh. Pada saat demikian biasanya harga ikan melambung tinggi. Namun tidak ada ikan yang bisa dijual karena mereka tidak berani melaut. Kecuali hanya satu dua nelayan saja yang tetap nekat melawan cuaca yang tidak mendukung. Saat hasil tangkapan melimpah, biasanya harga ikan akan cepat turun. Bahkan kadang tidak laku sama sekali. Akhirnya banyak ikan yang tidak terjual dan lama-lama busuk. Solusi akhir biasanya dijadikan ikan asin. Itupun sangat bergantung pada musim panas. Jika musim hujan, para nelayan mengalami kendala untuk mengeringkan ikan-ikan tersebut.
Selama ini para nelayan juga masih sangat tergantung kepada tengkulak ikan. Mereka tidak punya kemampuan untuk menjual/memasarkan sendiri agar memiliki harga yang jauh lebih baik. Hal ini lah yang menyebabkan kesejahteraan nelayan masih sangat rendah.

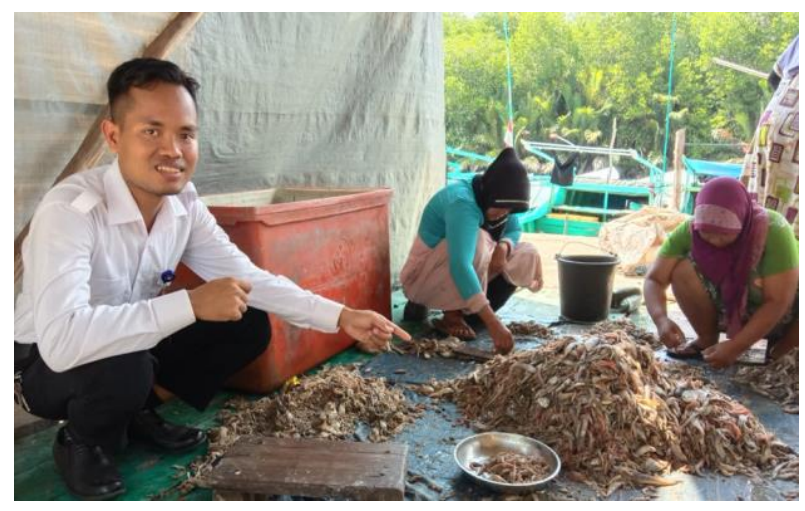

Gambar 2. Ketua tim (Anton Kuswoyo, S.Si., M.T.) melihat hasil tangkapan nelayan berupa udang. Kepala udang menjadi limbah yang dibuang begitu saja. (Sumber: Kuswoyo, 2019)

Permasalahan utama yang dihadapi mitra adalah:

1. Harga ikan hasil tangkapan naik turun dan bahkan cenderung murah sehingga penghasilan nelayan pas-pasan. Saat ikan banyak harga murah, bahkan kadang ikan tidak laku sehingga busuk atau hanya dijadikan ikan asin. Proses pembuatan ikan asin juga terkendala saat musim hujan.

2. Sebagian hasil tangkapan (25\%-30\%) hanya menjadi limbah yang tidak laku dijual, sehingga mengurangi pendapatan nelayan. Limbah perikanan tersebut berupa ikan-ikan kecil, ikan rusak/busuk, kepala udang, cangkang kepiting, dan kotoran/jeroan ikan.

3. Selama ini mitra belum memiliki kemampuan manajemen usaha, belum bisa mengolah hasil perikanan, dan belum memiliki keterampilan pemasaran produk (ikan hasil tangkapan), sehingga masih sangat tergantung pada tengkulak ikan.

Melihat latar belakang di atas, maka dirasa perlu diadakan kegiatan pengabdian kepada masyarakat berupa Program Kemitraan masyarakat (PKM) Pelatihan Pembuatan Ikan Asap dan Pengolahan Limbah Perikanan Menjadi Pakan Puyuh.

Tujuan Kegiatan PKM yaitu:

1. Memberikan pelatihan cara pembuatan ikan asap kepada mitra agar mitra mampu mengolah ikan asap.

2. Memberikan pelatihan cara mengolah limbah perikanan menjadi pakan puyuh, agar mitra mampu meningkatkan nilai guna (added velue) limbah perikanan. 
3. Memberikan pelatihan tentang strategi pemasaran (marketing), agar mitra mamiliki keterampilan memasarkan hasil olahan ikan asap maupun pakan puyuh dari limbah perikanan.

\section{METODE PELAKSANAAN}

Kegiatan Program Kemitraan Masyarakat (PKM) dilaksanakan bulan Juli-Oktober 2020 di pesisir Pantai Kuala Tambangan Kecamatan Takisung Kabupaten Tanah Laut, Kalimantan Selatan. Meskipun bertepatan dengan adanya pandemi Covid-19, namun kegiatan PKM tetap dilaksanakan, tentunya dengan mematuhi protokol kesehatan yaitu: pakai masker, jaga jarak, selalu cuci tangan dengan sabun dan air mengalir.

Metode penelitian terdiri dari tiga bagian yaitu pelatihan pembuatan ikan asap, pelatihan pengolahan limbah perikanan menjadi pakan puyuh, dan pelatihan pemasaran produk.

A. Alur proses pembuatan ikan asap adalah sebagai berikut:

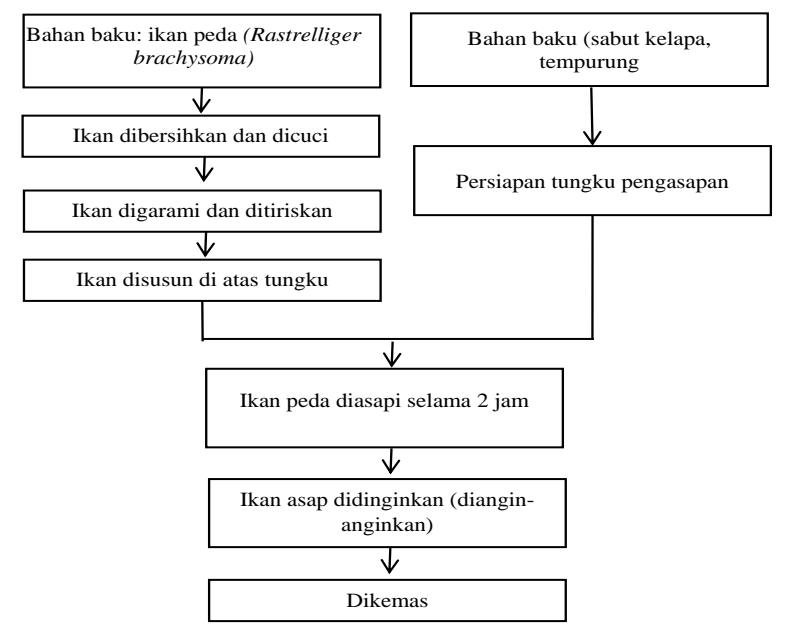

Gambar 3. Diagram alir proses pembuatan ikan asap

B. Proses pembuatan pakan puyuh dari limbah perikanan

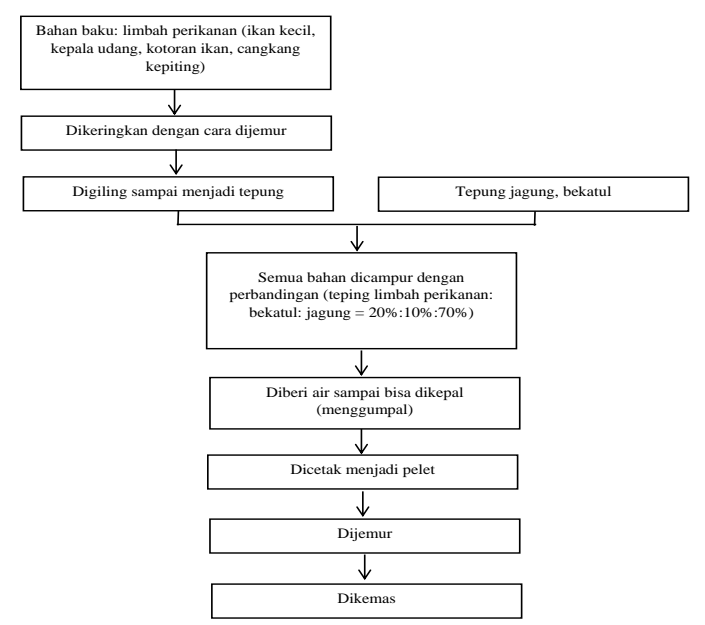

Gambar 4. Diagram alir proses pengolahan limbah perikanan menjadi pakan puyuh
C. Pelatihan strategi pemasaran (marketing)

Pada tahap ini, nelayan diberi pelatihan berupa ceramah/presentasi mengenai strategi pemasaran (marketing) usaha ikan asap dan pakan puyuh. Strategi pemasaran yang akan diberikan berupa pemasaran konvensional (door to door) dan pemasaran online melalui media sosial.

\section{HASIL dan PEMBAHASAN}

\section{Pelatihan Pembuatan Ikan Asap}

Bahan yang digunakan dalam pelatihan pembuatan ikan asap adalah ikan peda atau ikan kembung (Rastrelliger brachysoma) sebanyak 10 $\mathrm{kg}$. Ikan yang dipilih ialah ikan yang masih segar, bukan ikan yang sudah lama. Hal ini untuk menjaga mutu ikan. Menurut Metusalach (2012) satu diantara beberapa faktor yang mempengaruhi penurunan mutu ikan ialah waktu, semakin lama waktu maka proses penurunan mutu ikan semakin cepat.

Tahap awal ikan dibersihkan dari kotorannya dan dicuci sampai bersih. Penanganan dan penempatan ikan secara higienis akan berpengaruh pada kualitas ikan yang akan diolah lebih lanjut. Penempatan ikan pada wadah yang tidak sesuai, misalnya pada wadah bersuhu tinggi, tekena sinar matahari langsung, tempat yang kotor dan lain sebagainya, akan mempercepat penurunan mutu ikan.

Sebelum proses pengasapan, ikan diberi garam secukupnya. Proses penggaraman selain agar ikan memiliki rasa, juga agar mengombinasikan proses penggaraman, pemanasan dan pelekatan komponen kimiawi asap, (Prasetyo, dkk. 2015). Ikan yang sudah diberi garam selanjutnya dianginanginkan agar kering. Pratama, dkk. (2012) menyebutkan bahwa sebelum bahan baku diolah menjadi ikan asap, ikan dilakukan pengeringan sehingga produk ikan asap yang dihasilkan mengkilap. Selain proses pengasapan, kualitas bahan baku juga memengaruhi mutu sensori dari produk ikan asap.

Metode pengasapan yang diterapakan pada kegiatan ini ialah pengasapan panas. Bahan baku (ikan laut) diletakkan di atas sumber asap dengan jarak sekitar 30-70 cm dan suhu yang digunakan antara $70^{\circ} \mathrm{C}-100^{\circ} \mathrm{C}$. Sulfiani, dkk. (2017) menyebutkan bahwa pada proses pengasapan ada dua metode yang sering digunakan yaitu pengasapan dingin yaitu bahan diletakkan jauh dari sumber asap dan pengasapan panas yaitu bahan diletakkan relatif lebih dekat dengan sumber panas (asap).

Peralatan yang digunakan untuk pengasapan ikan dibuat dari bahan besi plat stainless steel (anti karat). Alat pengasapan ini berukuran panjang 70 $\mathrm{cm}$, lebar $40 \mathrm{~cm}$, dan tinggi $100 \mathrm{~cm}$, terdiri dari lima rak. Bahan baku asap dari sabut dan tempurung kelapa. Alat ini dibuat oleh tim PKM. 


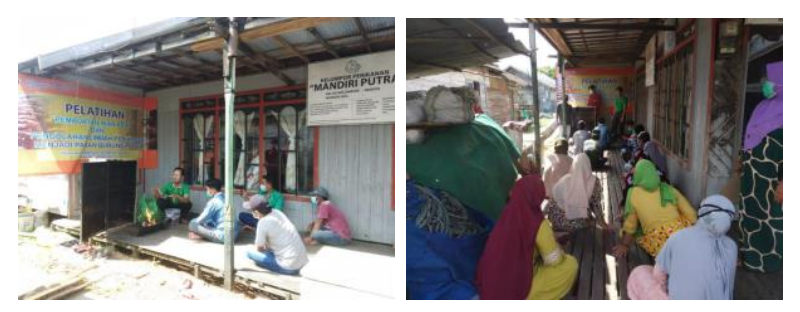

Gambar 5. Proses pelatihan pembuatan ikan asap. (Sumber: Kuswoyo, 2020)

Pengasapan diterapkan dengan tujuan mengawetkan ikan, meningkatkan cita rasa dan serta memperbaiki warna ikan dengan memanfaatkan senyawa-senyawa kimia yang ada pada asap. Ratna, dkk. (2011) menjelaskan bahwa bahan bakar asap dari tempurung dan sabut kelapa menghasikan produk ikan asap yang lebih digemari baik dari segi bentuk, warna, aroma dan rasa.

Pengasapan dilakukan selama sekitar 2 jam. Satu jam pertama dilakukan pembalikan ikan, bagian atas ikan menjadi di bagian bawah. Hal ini agar pengasapan merata di seluruh permukaan ikan. Pengsapan pada waktu yang singkat (kuang dari 2 jam) akan menyebabkan ikan tidak tahan lama dan berbau amis. Menurut Karyadi dan Sulistyowati (2010) waktu pengasapan yang sebentar berpengaruh pada kesempurnaan proses penguapan air dan senyawa volatile, salah satunya adalah yang menimbulkan aroma anyir (amis). Sedangkan menurut Isamu dkk. (2012), perbedaan nilai tekstur ikan asap diprediksi karena perbedaan kandungan air, dimana semakin tinggi kandungan air ikan asap, maka nilai teksturnya menjadi rendah, demikian pula sebaliknya.

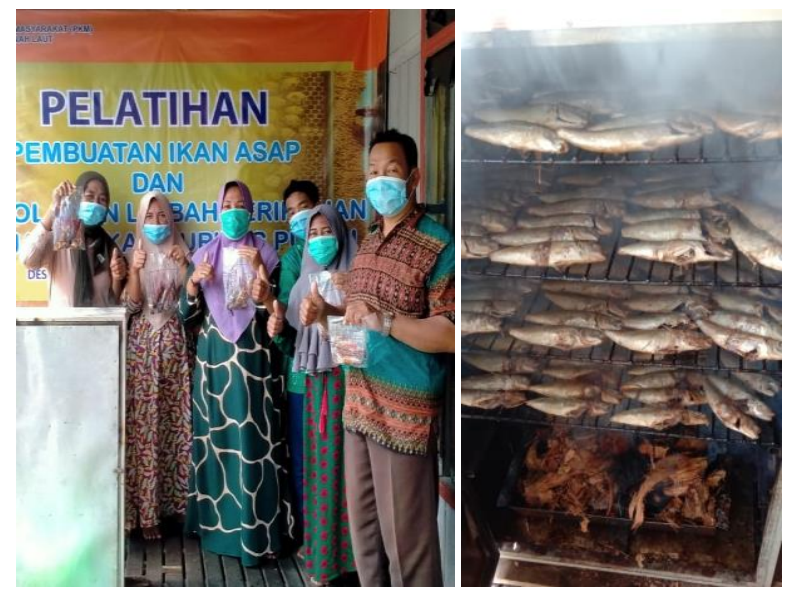

Gambar 6. Peserta pelatihan memperlihatakan ikan asap hasil olahannya, (Sumber: Kuswoyo, 2020)

Ikan asap yang sudah masak akan berwarna kuning keemasan. Warna ikan asap agak kekuning-kuningan dan mengkilat sesuai teori yang diungkapkan oleh Grace (2010) bahwa warna agak kekuning-kuningan pada ikan asap disebabkan karena ada reaksi antara fenol dan oksigen dari udara, yang terjadi setelah unsur asap tersebut mengalami pengendapan saat proses pengasapan.
Ikan kemudian diangkat dan didinginkan terlebih dahulu sebelum dikemas. Pengemasan dilakukan dengan menggunakan plastik khusus kemas dan kedua ujungnya dilekatkan menggunakan sealer plastic.

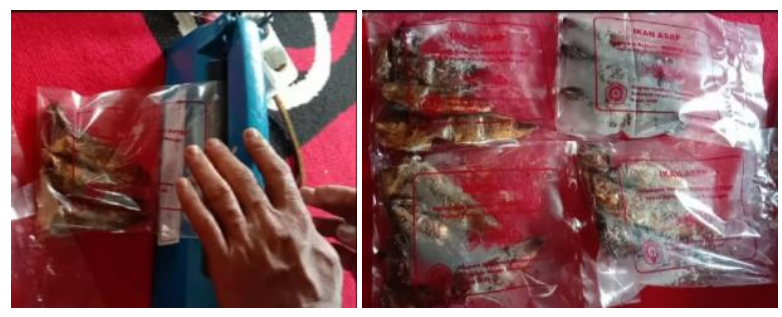

Gambar 7. Pengemasan ikan asap, (Sumber: Kuswoyo, 2020)

\section{Pengolahan Limbah Perikanan Menjadi Pakan Puyuh}

Puyuh memiliki beberapa keunggulan jika dibandingkan dengan unggas lain, diantaranya ialah pertumbuhan relatif cepat, kematangan kelamin lebih cepat, interval generasi yang sangat cepat dan produktifitas telur yang cukup tinggi. Puyuh bisa menghasilakan telur antara 250-300 butir/tahun dan biaya produksi yang relatif lebih murah (Subekti dan Hastuti, 2013). Pada saat ini usaha telur puyuh selain memproduksi telur juga memproduksi daging puyuh, (Widyatmoko, Zuprizal dan Wihandoyo, 2013). Kendala utama dalam dunia usaha peternakan khususnya puyuh adalah tingginya harga pakan yaitu mencapai 60 $70 \%$ dari total biaya produksi (Herlinae dan Yemima, 2016).

Oleh sebab itu, maka dalam kegiatan pengabdian ini selain memberi solusi terhadap pemanfaatan limbah perikanan bagi nelayan, juga memberi solusi kepada peternak puyuh dalam hal menghemat pakan. Hal ini karena pakan dari limbah perikanan harganya jauh lebih murah dibandingkan pakan buatan pabrik. Dalam aplikasinnya, tentu ternak puyuh tidak diberikan $100 \%$ pakan olahan, melainkan hanya sebagai pakan campuran saja. Meskipun demikian, sudah mengurangi biaya pakan.

Limbah perikanan yang digunakan berupa ikan yang tidak laku dijual (ikan-ikan kecil, ikan setengah busuk, kepala udang, cangkang kepiting). meskipun limbah, namun mengandung berbagai nilai gizi yang dapat digunakan untuk pakan unggas. Menurut Fachry dan Sartika (2010) limbah udang mengandung nutrisi yang sangat baik seperti protein $53,74 \%$, lemak $6,65 \%$, air $17,28 \%$, abu $7,72 \%$ dan khitin 14,61 \%. Limbah udang seperti kepala, kulit dan ekor mengandung senyawa kimia berupa protein, lemak, kalsium karbonat, abu, kithin dan kitosan. Demikian pula dengan limbah perikanan yang lainnya juga mengandung gizi yang diperlukan unggas (puyuh). 


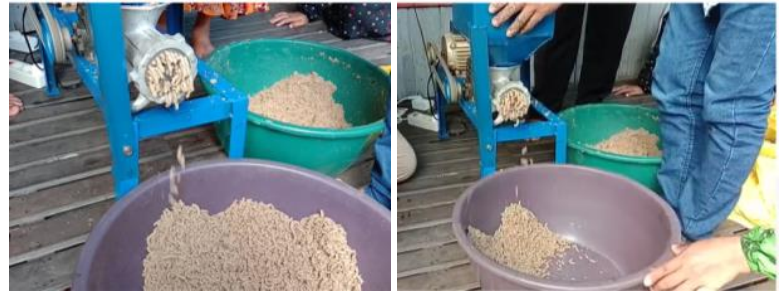

Gambar 8. Proses pembuatan pakan puyuh dari limbah perikanan, (Sumber: Kuswoyo, 2020)

Limbah perikanan dikeringkan terlebih dahulu di bawah terik sinar matahari. Setelah kering, limbah digiling hingga menjadi tepung. Tepung limbah perikanan tersebut selanjutnya dicampur dengan bekatul dan tepung jagung dengan perbandingan, tepung ikan: bekatul: tepung jagung = 20\%:10\%:70\%. Setelah diaduk rata, kemudian diberi air secukupnya hingga bahan menggumpal dan bisa dikepal. Selanjutnya adonan dicetak menjadi pelet menggunakan mesin giling rakitan. Mesin giling yang digunakan ini merupakan rakitan oleh tim pengabdian, dibuat dari alat giling bumbu/daging dan diberi penggerak motor listrik. Pelet pakan puyuh hasil cetakan dijemur terlebih dahulu sebelum dikemas/digunakan.

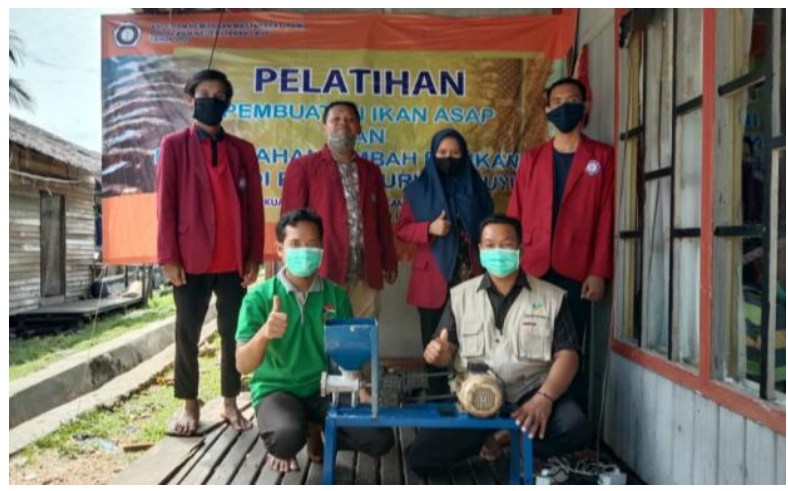

Gambar 9. Ketua Kelompok Nelayan "Mandiri Putra", Bapak Bayansyah menerima hibah alat pencetak pakan puyuh, (Sumber: Kuswoyo, 2020)

\section{Pelatihan pemasaran (marketing)}

Harus diakui bahwa sebagus apapun produknya, jika tidak dipasarkan dan tidak dibeli orang lain, maka sia-sia. Pembuatan produk tidak akan mengdatangkan penghasilan sebagaimana yang diharapkan. Pemasaran (marketing) adalah muara dari kegiatan produksi barang maupun jasa. Tidak terkecuali produksi ikan asap dan pakan puyuh.

Oleh sebab itu, pada kegiatan PKM ini, para nelayan dilatih mengenai strategi pemasaran agar produk yang dihasilkan laku dijual. Strategi pemasaran yang dilakukan dimulai dengan door to door yaitu mendatangi langsung ke rumah-rumah calon pelanggan. Selain itu juga dilakukan dengan menggunakan media sosial seperti Whatsapp Group (WAG), facebook, dll.

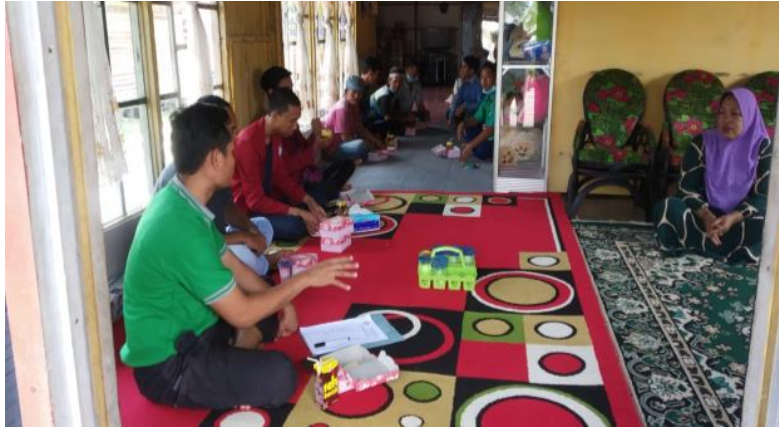

Gambar 10. Tim PKM memberikan penjelasan tentang strategi pemasaran (Sumber: Kuswoyo, 2020)

\section{KESIMPULAN}

Kesimpulan dari kegiatan PKM Pemberdayaan Kelompok Nelayan dalam Pembuatan Ikan Asap dan Pemanfaatan Limbah Perikanan Menjadi Pakan Puyuh di Desa Kuala Tambangan Kabupaten Tanah Laut, yaitu:

1. Mitra saat ini sudah mampu membuat ikan asap dan mengolah limbah perikanan menjadi pakan puyuh. Bahan baku pun tersedia cukup melimpah.

2. Ikan asap yang dibuat memiliki harga yang lebih tinggi dan ikan asap juga lebih awet jika dibandingkan dengan ikan yang tanpa diolah.

3. Limbah ikan menjadi lebih berguna dan bermanfaat dengan adanya pengolahan menjadi pakan puyuh.

4. Mitra telah mampu memasarkan secara langsung (door to door) maupun melalui media sosial. Namun berhubung saat ini masih terjadi pandemi Covid-19 maka masih memerlukan waktu untuk mengejar target penjualan.

\section{UCAPAN TERIMA KASIH}

Ucapatan terima kasih disampaikan kepada Direktorat Riset dan Pengabdian Masyarakat (DRPM) Kementerian Riset dan Teknologi/Badan Riset dan Inovasi Nasional yang telah memberi pendanaan pada Program Kemitraan Masyarakat (PKM) sehingga terlaksana kegiatan ini. Terima kasih juga kepada Pusat Penelitian dan Pengabdian kepada Masyarakat (P3M) Politeknik Negeri Tanah Laut, serta kepada Kelompok Nelayan "Mandiri Putra" Desa Kuala Tambangan Kecamatan Takisung, Kabupaten Tanah Laut atas dukungan dan kerjasamanya.

\section{DAFTAR PUSTAKA}

Fachry, A. R. dan Sartika, A. 2012. Pemanfaatan limbah kulit udang dan limbah kulit ari singkong sebagai bahan baku pembuatan plastik biodegradabible. Jurnal Teknik Kimia. 3(18): 1-9 
Grace, S. 2010. Oksidasi Lemak Ikan Tongkol yang Direndam Dalam Larutan Ekstrak Daun Sirih. Jurnal Pasific. 2(5). Fakultas Perikanan dan Ilmu Kelautan, UNSRAT. Manado.

Herlinae dan Yemima. 2016. Efektifitas berbagai probiotik kemasan terhadap pertumbuhan dan produksi burung puyuh (coturnix coturnix japonica). Jurnal Ilmu Hewani Tropika. 5(2), 95-100.

Isamu, K.T., Hari P., dan Sudarminto S. Y. 2012. Karakteristik Fisik, Kimia dan Organoleptik Ikan Cakalang (Katsuwonus pelamis) Asap di Kendari. Jurnal Teknologi Pertanian. 13(2): 105-110.

Karyadi dan Sulistyowati. 2010. Usaha Meningkatkan Ketrampilan Kelompok Pengrajin Ikan Asap Melalui Pelatihan dan Pendampingan Dengan Memakai Rumah Asap Hasil Modifikasi. Sekolah Tinggi Ilmu Pertanian.

Metusalach, Kasmiati, Fahrul, dan Jaya, I. 2012. Pengaruh Cara Penangkapan dan Cara Penanganan dengan Kualitas Ikan yang Dihasilkan. Jurnal IPTEKS PSP, 1(1) April 2014 14: $40-52$.

Prasetyo, D.Y.B, Darmanto, Y.S., Swastawati, F. 2015. Efek Perbedaan Suhu dan Lama Pengasapan terhadap Kualitas Ikan Bandeng (Chanos chanos Forsk) Cabut Duri Asap. Jurnal Aplikasi Teknologi Pangan. 4(3).
Pratama, R. I., Sumaryanto, H., Santoso, J., dan Zahirudin, W. 2012. Karakteristik Sensori Beberapa Produk Ikan Asap Khas Daerah Di Indonesia Dengan Menggunakan Metode Quantitative Descriptive Analysis. JPB Perikanan. 7(2): 117-130.

Ratna, Safrida dan Yulinar. Desember 2011. Variasi Jenis Bahan Bakar pada Pengasapan Ikan Bandeng (Chanos-chanos Forskal) Menggunakan Alat Pengasapan Tipe Kabinet. Jurnal Ilmiah Pendidikan Biologi, Biologi Edukasi. 3(2): 34-37.

Subekti, E. dan Hastuti, D. 2013. Budidaya puyuh (coturnix-coturnix japonica) di pekarangan sebagai sumber protein hewani dan penambah income keluarga. Jurnal Ilmu-ilmu Pertanian. 9(1): 1-10.

Sulfiani, Sukainah, A., dan Mustarin, A. 2017. Pengaruh Lama dan Suhu Pengasapan dengan Menggunakan Metode Pengasapan Panas terhadap Mutu Ikan Lele Asap. Jurnal Pendidikan Teknologi Pertanian. 3: S93-S101.

Widyatmoko, H., Zuprizal, dan Wihandoyo. 2013. Pengaruh Penggunaan Corn Dried Distillers Grains With Solubles dalam Ransum Terhadap Performan Puyuh Jantan. Buletin Peternakan, 37(2), 120-124. https://doi.org/10.21059/ buletin peternak. v37i2.2430.

www.port.tanahlautkab.go.id. 